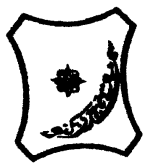

Bayero Journal of Pure and Applied Sciences, 11(1): 57 - 60

Received: November, 2017

Accepted: May, 2018

ISSN $2006-6996$

\title{
EFFECT OF FERTILIZER LEVELS AND PLANT SPACING ON THE PERFORMANCE OF Mucuna prureins (VELVET BEAN) IN THE NORTHERN GUINEA SAVANNA OF NIGERIA
}

\author{
Bature, M.S., Hassan, A.H., Jantar, H.J and Shu'aibu, A.S \\ College of Agriculture and Animal Science, Division of Agricultural Colleges, Ahmadu Bello University, Mando- \\ Road, Kaduna \\ Department of Agronomy, Institute of Agricultural Research, Ahmadu Bello University, Zaria \\ Corresponding Author (salisumusabature@gmail.com,GSM: 08065549941)
}

\begin{abstract}
Fertilizer recommendation for crop and plant spacing is dynamic process in view of the generation of new knowledge with management practices. Information such as (phosphorus levels and plant spacing) on maintaining adequate soil fertility is very much important for producing better forages for livestock. Leguminous crop such as Velvet bean (Mucuna pruriens) can alleviate some of these problems. Field experiment was conducted to access the effect of phosphorus fertilizer application level at 0, 80 and $120 \mathrm{~kg} / \mathrm{ha}$ and plant spacing interval of 30, 60 and $90 \mathrm{~cm}$ of Velvet bean. Application of $80 \mathrm{~kg} / \mathrm{ha}$ of phosphorus fertilizer significant/y influenced the performance of Mucuna plant such as plant height, number of branches and forage yield. Plant spacing interval of $30 \mathrm{~cm}$ resulted in better stand count, taller plant, higher number of branches and forage yield per plant. Famers in Northern Guinea Savanna of Nigeria can adopt the application of phosphorus fertilizer at $80 \mathrm{~kg} / \mathrm{ha}$ and using narrower spacing $(25 \mathrm{~cm}$ by $30 \mathrm{~cm})$ for better yield of Mucana, thereby increasing farm output and animal performance.
\end{abstract}

Key words: phosphorus level, plant spacing, Mucuna pruriens, Velvet bean

\section{INTRODUCTION}

Velvet bean (Mucuna pruriens), is probably a native to tropical southern or southeastern Asia (Houngnandan et al., 2012). It is naturalized in tropical and subtropical areas around the world including the West Indies, Mexico and South America (Diollo and Berhe, 2003). Humphres and Riveros (1986), suggest that the species was probably introduced into Mesoamerica in the 1920 s by the United Fruit Company as a forage crop for the company's mules on banana plantations. Houngnandan et al.(2012) had previously listed the species as 'probably native' in Puerto Rico and the Virgin Islands, but later became convinced that the species is likely "exotic and naturalized" in Puerto Rico as well as the Virgin Islands, Lesser Antilles, the US, Mexico, and South America. Mucuna pruriens seeds are dispersed by water and in soil. The species was introduced outside of its native range both intentionally in agricultural settings, and unintentionally. It became invasive in many of its introduced places including the Mariana Islands, Fiji and New Guinea and West Africa (Kavitha and Vadivel, 2008). As a tropical legume plant, Velvet bean ( $M$. pruriens) has potential of energy and protein supplement in livestock feeds. The foliage is frequently fed to grazing animals and the beans are sometimes eaten by humans and animals (Kavitha and Vadivel, 2006b). The whole plant can be fed to animals as silage, dried hay or dried seeds. $M$. pruriens silage contains $11-23 \%$ crude protein, 35$40 \%$ crude fiber, and the dried beans $20-35 \%$ crude protein. The objectives of the study were:

To determine the effect of phosphorus levels $(0,80$ and $120 \mathrm{Kg} / \mathrm{ha}$ ) on fresh and dry matter yield of Velvet bean (Mucuna pruriens). To determine the effect of plant spacing $(25 \mathrm{~cm}$ by $30 \mathrm{~cm}, 25 \mathrm{~cm}$ by $60 \mathrm{~cm}$, and $25 \mathrm{~cm}$ by $90 \mathrm{~cm}$ ) on growth components of Velvet bean (Mucuna pruriens).

\section{MATERIALS AND METHODS}

The study was conducted at the pasture and range unit of teaching and research farm, College of Agriculture and Animal Science, Ahmadu Bello university, Mando Road- Kaduna (latitude $10^{\circ} 20^{\prime} \mathrm{N}$ and longitude $07^{\circ} 45^{\prime} \mathrm{E}$ with an elevation of 632 meters sea level), in the northern guinea savanna ecological zone of Nigeria.The zone is characterized by a rainy season that starts in April/May, stabilize in June and end in early October. The mean annual rainfall is $1,100 \mathrm{~mm}$, maximum temperature varies between $27^{\circ} \mathrm{C}$ to $35^{\circ} \mathrm{C}$, depending on the season. The relative humidity is about $72 \%$. The dry season begins with a period of dry cool weather called harmattan that last from October to January. The harmattan is followed by a dry hot weather from February to April (Nimet, 2017).

\section{Soil Sampling}

A composite soil sample was obtained from the experimental plots using a soil auger at a depth of $15 \mathrm{~cm}-30 \mathrm{~cm}$ before establishing the plots at the beginning of the experiment. The soil sample was analyzed for physical and chemical properties such as Clay, Silt, Sand, pH, total N, available P, organic C, exchangeable bases, $\mathrm{Ca}^{2+}, \mathrm{Mg}+, \mathrm{K}^{+}, \mathrm{Na}^{+}$, cation exchange capacity and exchangeable acidity, using standard procedure as described by Black (1968), to determine the pre-planting nutrient status of the soil at the Department of Soil Science, Ahmadu Bello University, Zaria. 


\section{Source of mucuna seeds and NPK Fertilizer}

Two kilograms $(2 \mathrm{~kg})$ of Mucuna pruriens seeds and $25 \mathrm{~kg}$ of phosphorus and NPK fertilizer were obtained from Feed and Nutrition Research Program of National Animal Production Research Institute (NAPRI) Shika, Nigeria. The source of phosphorus was single super phosphate $(18 \% \mathrm{P})$ which was broadcast on the day of sowing.

\section{Treatments and Experimental Design}

The treatments consisted of combination of three phosphorus rates $(0,80,120 \mathrm{~kg} / \mathrm{ha})$ and three plant spacing $(25 \mathrm{~cm} \times 30 \mathrm{~cm}, 25 \mathrm{~cm} \times 60 \mathrm{~cm}$ and $25 \mathrm{~cm} \times 90 \mathrm{~cm})$. The experiment was laid out in a $3 \times 3$ factorial arrangement in a randomized complete block design (RCBD) with three replications. There were total of 27 net plots, inform of basins measuring $4 \mathrm{~m}^{2}$ with $1 \mathrm{~m}$ inter-row path and watering channels.

\section{Forage Establishment and Management}

The field was ploughed, harrowed to a fine tilth manually using a hand hoe before planting. There were total of 27 net plots inform of basins measuring $4 \mathrm{~m}^{2}$ with $1 \mathrm{~m}$ inter-row path and watering channels. All experimental plots received $40 \mathrm{kgNPK} / \mathrm{ha}$ as uniform dressing by incorporating it into the soil before sowing. Two mucuna seeds were sown manually per hole, while the field was maintained weed free throughout the trial period, using hoe weeding at 3 and 6 WAS.

\section{Observation and Data Collection \\ Stand Count}

Stand count was recorded at 4 weeks after sowing by counting the number of stands in each plot.

Plant Height: The heights of 3 tagged plants in each plot were measured from the ground level to the tip of the plant using a meter rule.

Number of Leaves: These were obtained by counting the number of leaves and recording the average of 3 tagged plants in each plot.

Number of Branches: Number of branches were counted and recorded the average of 3 tagged plants in each plot.

Fresh and Dry Forage Yield: The fresh forage material cut $5 \mathrm{~cm}$ above the ground level were weighed immediately using a hanging scale to determine the fresh forage yield. A sample of 150$200 \mathrm{~g}$ fresh material was weighed, oven dried at $65^{\circ} \mathrm{C}$ for $48 \mathrm{hrs}$ and reweighed to give an estimate of the percent (\% ) dry matter, while the dry matter production was obtained using the formula below:

Dry matter $(\mathrm{kg} / \mathrm{ha})=$ Total fresh weight in $\mathrm{Kg} \times \%$ Dry matter

\section{Statistical Analysis}

Data collected for the experiment were subjected to analysis of variance (ANOVA) by using procedure of Statistical Analysis System (SAS, 2003). Probability level of significance at $5 \%(\leq 0.05)$ to separate treatment means was adopted using Duncan's Multiple Range Test (Duncan, 1955).

\section{RESULTS}

Table 1 shows the effect of phosphorus level and plant spacing on stand count of Mucuna at 3 weeks after sowing (WAS). Phosphorus application show no significant ( $p>0.05$ ) on stand count of Mucuna plant. Differences among spacing were significant $(p<0.05)$, whereas plant spacing $(25 \mathrm{~cm} \times 30 \mathrm{~cm})$ produced more number of stands than both $(25 \mathrm{~cm} \times 60 \mathrm{~cm}$ and $25 \mathrm{~cm} \times 90 \mathrm{~cm}$ ) plant spacing.

Table 2shows the effect of phosphorus levels and plant spacing on plant height of Mucuna at 3, 6 and 9 WAS. Phosphorus application levels, showed an increasing trend $(p<0.05)$ in the height of plant with $120>80>0 \mathrm{kgP} / \mathrm{ha}$ across the treatments at 3 and 6 WAS. But at 9WAS, the means with phosphorus application were significantly similar compared to the control. There was a significant $(p<0.05)$ increase in the height of Mucuna plant both at 3 and 6WAS with $(25 \mathrm{~cm} \times 30 \mathrm{~cm}$ and $25 \mathrm{~cm} \times 60 \mathrm{~cm})$ plant spacing compared to $(25 \mathrm{~cm} \times 90 \mathrm{~cm})$ plant spacing. But at 9WAS, there was no significant increase $(p>0.05)$ in height of plant across all the spacing treatments.

Table 3 shows the effect phosphorus level and plant spacing on number of branches of Mucuna at 3, 6 and 9 WAS. Application of phosphorus rates show an increasing trend $(p<0.05)$ in number of branches with $120>80>0 \mathrm{~kg} / \mathrm{ha}$ at 3 WAS. But it does not show a significant difference $(p>0.05)$ in the number of branches at 6WAS. At 9WAS, there was a significant difference $(p<0.05)$ in number of branches with phosphorus application. There was a significant increased $(p<0.05)$ in number of branches with $(25 \mathrm{~cm} \times 30 \mathrm{~cm}$ and $25 \mathrm{~cm} \times 60 \mathrm{~cm})$ plant spacing compared to $(25 \times 90)$ plant spacing at 3 WAS. At 6WAS, no significant difference was observed across all the spacing. However, the means for $(25 \mathrm{~cm} \times 30 \mathrm{~cm})$ and $(25 \mathrm{~cm} \times 90 \mathrm{~cm})$ plant spacing were significantly similar than for $25 \mathrm{~cm} \times 60 \mathrm{~cm}$ plant spacing at 9WAS. Plant spacing $(25 \mathrm{~cm} \times 60 \mathrm{~cm})$ was observed to produce the highest number of branches at 9WAS.

Table 4 shows the effect of phosphorus levels and plant spacing on fresh and dry matter yield of Mucuna during the harvesting period. The application of phosphorus rates produced more fresh and dry matter yield than the control level. Application of phosphorus at 80 and $120 \mathrm{kgP} / \mathrm{ha}$ was significantly similar during the harvesting period. There was an increase $(p<0.05)$ in fresh and dry matter yield with $(25 \mathrm{~cm} \times 30 \mathrm{~cm}$ and $25 \mathrm{~cm} \times 60 \mathrm{~cm})$ plant spacing compared to $(25 \mathrm{~cm} \times 90 \mathrm{~cm})$ plant spacing. Plant spacing $(25 \mathrm{~cm} \times 30 \mathrm{~cm}$ and $25 \mathrm{~cm} \times 60 \mathrm{~cm})$ were significantly similar across the treatments for fresh and dry matter yield, but $(25 \mathrm{~cm} \times 30 \mathrm{~cm})$ produced statistically higher fresh and dry matter yield compared to $(25 \mathrm{~cm} \times 60 \mathrm{~cm})$ plant spacing. 
Table 1: Effect of Phosphorus Level and Plant Spacing on Stand Count of Mucuna at 3 WAS.

\begin{tabular}{|c|c|}
\hline Treatments & Stand count \\
\hline \multicolumn{2}{|c|}{ Phosphorus (kg/ha) } \\
\hline 0 & 18.11 \\
\hline 80 & 21.11 \\
\hline 120 & 18.22 \\
\hline \multicolumn{2}{|l|}{ Spacing } \\
\hline $25 \times 30$ & $26.22^{\mathrm{a}}$ \\
\hline $25 \times 60$ & $19.00^{b}$ \\
\hline $23 \times 90$ & $12.22^{\mathrm{C}}$ \\
\hline SEM & 1.24 \\
\hline p-value & 0.0001 \\
\hline
\end{tabular}

Table 2: Effect of Phosphorus Level and Plant Spacing on Plant Height of Mucuna at 3, 6 and 9 WAS.

\begin{tabular}{|c|c|c|c|}
\hline \multirow[b]{2}{*}{ Treatments } & \multicolumn{3}{|c|}{ Plant height } \\
\hline & 3 WAS & 6 WAS & 9 WAS \\
\hline \multicolumn{4}{|c|}{ Phosphorus level (kg/ha) } \\
\hline 0 & $30.31 a$ & $101.91 b$ & $154.31 b$ \\
\hline 80 & $33.64 a b$ & $114.94 a b$ & $209.56 a$ \\
\hline 120 & $41.24 a$ & $128.26 a$ & $213.62 a$ \\
\hline \multicolumn{4}{|l|}{ Spacing } \\
\hline $25 \times 30$ & $38.86 a$ & $116.82 b$ & 191.60 \\
\hline $25 \times 60$ & $39.64 a b$ & $135.03 a$ & 208.49 \\
\hline $25 \times 90$ & $26.75 b$ & $93.26 \mathrm{~b}$ & 197.40 \\
\hline SEM & 2.96 & 4.53 & 6.32 \\
\hline p-value & 0.0058 & 0.013 & 0.0178 \\
\hline
\end{tabular}

Table 3: Effect of Phosphorus Level and Plant Spacing on Number of Branches of Mucuna at 3, 6 and 9 WAS.

\begin{tabular}{llll}
\hline \multicolumn{2}{l}{ Number of branches } & \\
\hline Treatments & $\mathbf{3}$ WAS & $\mathbf{6}$ WAS & WAS \\
\hline Phosphorus level $(\mathrm{kg} / \mathrm{ha})$ & $10.60 \mathrm{~b}$ & 24.04 & $45.40 \mathrm{~b}$ \\
80 & $11.66 \mathrm{ab}$ & 41.02 & $75.06 \mathrm{a}$ \\
120 & $12.66 \mathrm{a}$ & 28.16 & $72.84 \mathrm{a}$ \\
Spacing & & & \\
$25 \times 30$ & $12.57 \mathrm{a}$ & 22.96 & $59.53 \mathrm{~b}$ \\
$25 \times 60$ & $12.08 \mathrm{a}$ & 32.22 & $77.44 \mathrm{a}$ \\
$25 \times 90$ & $10.26 \mathrm{~b}$ & 38.04 & $56.33 \mathrm{~b}$ \\
SEM & 1.12 & 4.72 & 2.93 \\
p-value & 0.0021 & 0.327 & 0.0001 \\
\hline
\end{tabular}

Means within a column of any set of treatment group with unlike letter(s) are significantly different at $(p<0.05)$ $\mathrm{SEM}=$ Standard Error of Mean WAS = Weeks after sowing.

Table 4: Effect of Plant Spacing and Phosphorus Level on Fresh and Dry Matter Yield of Mucuna during the harvesting period

\begin{tabular}{|c|c|c|c|c|}
\hline Treatments & $\begin{array}{ll}\begin{array}{l}\text { Fresh } \\
\text { (Kg/ha) }\end{array} & \text { Matter } \\
\end{array}$ & Yield & Dry Matter Yield & (Kg/ha) \\
\hline \multicolumn{5}{|c|}{ Phosphorus level(kg/ha) } \\
\hline 0 & $1133.55^{b}$ & & $1013.78^{a}$ & \\
\hline 80 & $1169.16^{a}$ & & $1004.50^{\mathrm{ab}}$ & \\
\hline 120 & $1174.72^{\mathrm{a}}$ & & $1014.11^{a}$ & \\
\hline \multicolumn{5}{|l|}{ Spacing } \\
\hline $25 \times 30$ & $1118.50^{\mathrm{a}}$ & & $1024.22^{a}$ & \\
\hline $25 \times 60$ & $1111.38^{\mathrm{a}}$ & & $1030.58^{a}$ & \\
\hline $25 \times 90$ & $973.55^{\mathrm{b}}$ & & $1000.67^{b}$ & \\
\hline SEM & 17.28 & & 16.003 & \\
\hline p-value & 0.331 & & 0.236 & \\
\hline
\end{tabular}


DISCUSSION

Effects of Phosphorus Levels on the Performance and Forage Yield of (M. pruriens).

The application of phosphorus rates in this trial produced more growth components and forage yield than the control level. This might be related to plants having access to greater share of available nutrients (response to phosphorus) in the soil which resulted in improved growth performance. The observed increased in growth components and forage yield with phosphorus application agrees with the report of Kumwenda and Gilbert (2002) and Kavitha (2005) on mucuna plant. Application of phosphorus at 80 and $120 \mathrm{KgP} / \mathrm{ha}$ was significantly similar during the harvesting period. This indicates that $80 \mathrm{KgP} / \mathrm{ha}$ might be optimum phosphorus fertilization in Mucuna pruriens.

\section{Effect of Plant Spacing on the Performance and} Forage Yield of (M. pruriens)

Results of this trial had shown that there was significant response on stand count, plant height, number of branches and forage yield per plant. Spacing among plant stands influenced the degree of intra plant competition for available resources. However, the heights of the plant at spacing $(25 \mathrm{~cm} \times 30 \mathrm{~cm}$ and $25 \mathrm{~cm} \times 60 \mathrm{~cm})$ were found to be slightly higher than at wider spacing $(25 \mathrm{~cm} \times 90 \mathrm{~cm})$, this is because there was high competition for sunlight, hence growing taller. Kumwenda and Gilbert

\section{REFERENCES}

Black, C. A (1965). Method of soil analysis 11. Chemical and microbiological properties. American Society of Agronomy Madison, Wisconsin $1575 \mathrm{P}$

Diallo O. K and Berhe T (2003). Processing the Mucuna for Human Food in the Republic of Guinea.Tropical and Subtropical Agro Ecosystem Journal 1(2/3):193-196

Duncan, D.B (1955). Multiple Range and Multiple F Biometric 11: 1-42

Farooqi, A.Aand Vasundhara M (1999). Production technology of medicinal and aromatic crops. Natural Remedies Pvt. Ltd., Bangalore, India pp. 26-28.

Houngnandan P Sanginga N, Okogun A, Vanlauwe B, Merekx R, Cleemput O (2012). Assessment of soil factors limiting growth and establishment of Mucuna in farmer's fields in the derived savanna of the Benin Republic. Biological Science Journaß3(5):416-422.

Humphreys L.R and Riveros F (1986). Tropical pasture seed production. FAO, Rome. pp. 43-52.

Kavitha C and Vadivel E (2005). In vitro production of L DOPA from Mucuna pruriens (L.) DC. Biochem. Cell. Arch. Journal5(2):161-168.
(2002) reported similar results. The total yield per unit land area depends on the number of plants per unit's area. Also, it had been reported that mucuna produced high forage yield at advanced stage of maturity compared to with the early stage of maturity (Farooqi et al., 1999).

\section{CONCLUSION}

From the results of the trial, it is clear that Mucuna pruriens is influenced by phosphorus application and plant spacing. Famers in Nigeria could plant Mucuna pruriens at narrower spacing using $80 \mathrm{Kg} / \mathrm{ha}$ phosphorus application if is to be harvested at 9WAS. This will help to famers to save extra cost of fertilizer, thereby increasing farm output and animal performance.

\section{RECOMMENDATION}

Mucuna pruriens should be allowed to reach maximum maturity (seed yielding stage) so as to see the effect of spacing. Seeds of Mucuna should be made available to famers to encourage its incorporation into the farming system for higher yield. CONTRIBUTION: Bature, M.S.; Hassan, A.H.; Jantar, H.J and Shuaibu, A.S, did the study and wrote the protocol. Author Bature, M.S, managed the analysis of the study and literature reviews. All authors read and approved the final manuscript.

COMPETING INTEREST: No competing interests exist.

Kavitha C,and Vadivel E (2006a). Effect of organic manures and inorganic fertilizers on growth characters of Mucuna pruriens (L.). Plant Arch. 6(1):197-200.

Kavitha C,and Vadivel E (2006b). Effect of organic manures and inorganic fertilizers on yield and yield attributing characters of Mucuna pruriens (L.). J. Med. Aromas Plant ScienceJournal 28:18-22.

Kavitha C,and Vadivel E (2008). Effect of organic manures and inorganic fertilizers on dry matter production and L DOPA content of Mucuna pruriens (L.) DC. - A leguminous medicinal Legume Research Journal. 31(1):44-47.

Kumwenda J.B.T and Gilbert R (1998). Biomass production by legume green manures on exhausted soils in Malawi: A soil fertility network trial. In: Proceedings of the Soil Fertility Network Results and Planning Workshop, Africa University, Mutare, Zimbabwe pp. 85-86.

Nimet (2017). Nigerian Meteorological Agency, National Air Port Authority- Kaduna

SAS Institute (2003). Statistical Analysis Software, Data watch.com 